\title{
THE SCIENTIFIC CONTRIBUTIONS OF MEDICAL UNDERGRADUATES IN LONDON*
}

by

WILLIAM CARLETON GIBSON

ONE hundred years ago this evening it is safe to say that William Osler was struggling to keep up his Latin prose compositions while spending most of his time as a theological student at Trinity College, Toronto, on zoological pursuits. The enquiring mind which was to make him a great medical diagnostician was already at work in differentiating and classifying freshwater polyzoa collected from many parts of the newly-confederated country, Canada. Osler's move from theology to medicine was already under way and his reading was moving in the direction of Sir Thomas Browne, Darwin, Lyell, Herbert Spencer and Thomas Huxley. Osler's 'ink-pot career' was about to begin and his highly original graduation thesis, on pathological anatomy, with thirty-three microscopic specimens, was a scant five years away. ${ }^{1}$ The prose style adopted in the introduction to his thesis was to characterize much of Osler's prolific writing, and in retrospect, some would say it marked him out clearly as a future Regius Professor at Oxford! He began: 'In that Trinity of being -of body, mind and soul-which so marvellously make up the man, each one has its own special ills and diseases . . . To investigate the causes of death, to examine carefully the condition of organs, after such changes have gone on in them as to render existence impossible and to apply such knowledge to the prevention and treatment of disease, is one of the highest objects of the Physician.'2

It is perhaps appropriate that this meeting of the Club named to honour Osler should discuss, in retrospect, the lives of undergraduates, in London hospital medical schools, who have made significant contributions to science. Osler lived for his students and for their development as acute observers of nature. Were he here with us tonight he could probably add to the number of young contributors to be discussed.

I have divided the thirty young men on my list according to the hospital medical schools in which they enrolled. Sometimes an individual studied at more than one school as an undergraduate. In addition I have introduced brief notes concerning the great teachers, in the respective schools, who have fostered student research.

Perhaps it would be appropriate to begin with the students of University College Hospital where we meet with pleasure this evening. The first Professor of Physiology here was William Sharpey. He inspired two of the youthful contributors about to be discussed, James Blake (1815-1893) and Joseph Lister (1827-1912).

Blake has been memorialized as 'the Gold Rush physician of California' by Professor Chauncey Leake. ${ }^{3}$ Little known and rarely mentioned today though he was a brilliant student of this hospital, Blake served an apprenticeship with Thomas Graham, the distinguished colloid chemist, and then came under the spell of William

* Read before the Osler Club of London, 14 November 1967. 


\section{W. C. Gibson}

Sharpey. Through him he developed an interest in the cardiovascular system, and in 1838 began his study of the effects of intravascular injections of various salts and of drugs such as nicotine, morphine and strychnine. He measured the circulation time, surely one of the first to do so. His paper, which was read at a meeting of the British Association, appeared a year later in the Edinburgh Medical and Surgical Journal, ${ }^{2}$ thanks probably to Sharpey's efforts. In the ensuing summer Blake studied with François Magendie in Paris, and in his laboratory may have made the acquaintance of Claude Bernard, a scientist for whom he entertained a life-long reverence. Blake the undergraduate seems to have met Poiseuille in Paris, and brought home to London, as a result, one of the haemodynamometers which Poiseuille had first described in his Paris thesis of 1828, 'Recherches sur la force du coeur aortique'. As a senior medical student, in the year 1839, Blake published in the Lancet his observations on the permanent obliteration of veins by even slight irritation. Simultaneously his work on chemical structure and physiological effect was communicated to the Academy of Science in Paris. Blake was quick to see that his method might reveal the chemical constitution of the 'target organs'.

Of his postgraduate studies suffice it to say that Blake arranged those chemical elements which he was able to test in a series which pre-dated Mendeleev's 'Periodic Table' by twenty years. After teaching anatomy and surgery at the University Medical College in St. Louis, Missouri, from 1847 to 1850 , Blake moved on to the gold fields of California, where he pioneered the fresh-air treatment of tuberculosis, edited the Pacific Medical and Surgical Journal, and taught in the University of California's forerunner, Toland Medical College. In summary, Blake lived a long and varied life, a worthy pupil of Sharpey and an imaginative product of University College Hospital.

Joseph Lister, the Quaker son of a distinguished microscopist and wine merchant, entered University College Hospital with a Bachelor of Arts degree. Under William Sharpey's guidance he developed an interest in the muscle fibres of the human iris. ${ }^{4}$ His paper on the former structures appeared on page 8 of the first volume of the Quarterly Journal of Microscopical Science, a distinction which few students could claim. It is, moreover, a very substantial paper, and Lister, in his final year of undergraduate studies is pretty sharp in his criticism of Bowman's view. He says, in part: 'Bowman, on the other hand, states that, while in some instances a delicate narrow band of circular fibres exist at the very verge of the pupil, yet, in the majority of instances, he feels sure that no such constrictor fibres of the pupil exist. He ascribes the contraction of the pupil to the inner part of the radiating fibres, which, he says, are joined and knotted in a plexiform manner round the pupil. It is scarcely needful to observe that such a statement from such an authority could not but go far to impugn Professor Kolliker's assertion respecting the existence of a sphincter pupillae.'

Lister concludes: 'My experience, I must confess, accords with that of Kolliker, viz. that the sphincter is readily seen, while the dilator is that whose investigation alone presents very serious difficulty.' It should be remembered that Lister's work was based on human iris tissue removed at operation by Wharton Jones, the physiologistsurgeon who, with Charles Babbage the mathematician, had just missed inventing a workable ophthalmoscope before Helmholtz's triumph in 1850. The microscopic technique which Lister applied to this undergraduate study of smooth muscle was to 


\section{Scientific Contributions of Medical Students in London}

be the key to the unsolved problem of 'hospital gangrene' and sepsis in wounds. Just as Blake investigated venous inflammation with Sharpey, so did Lister study blood coagulation and inflammation in the frog's web.

Another of Sharpey's pupils was the prolific John Burdon Sanderson who was to become Professor of Physiology at University College in the years of Osler's postgraduate training here. Michael Foster and E. A. Schafer were also pupils of Sharpey, so that one man's influence fanned out in a remarkable manner, influencing several generations. Thus we find Frederick Augustus Dixey (1855-1935), memorialized by Miss Jessie Dobson ${ }^{5}$ so felicitously as one of the 'pioneers of osteogeny', sitting at the feet of Sharpey-Schafer here, and carrying on undergraduate researches on bone formation in the fingers and toes.

Victor Horsley, the father of modern brain surgery, ${ }^{6}$ was one of Burdon Sanderson's prolific pupils, and read two research reports to the students' Medical Society at University College Hospital. One concerned the endings of tendons in the rat's tail. The other dealt with intervertebral discs. As a gifted artist, second only to his father, who was the inventor of the modern Christmas card, Horsley illustrated a lecture by William Gowers on the relation of the spinal nerves to the vertebral column. He also assisted Bastian with his book, The Brain as an Organ of the Mind, and also contrived to do some student research in bacteriology with F. W. Mott. Horsley, in turn, taught Thomas Lewis, another distinguished student contributor at University College Hospital, and so the chain goes on! A paper on the haemolymph system was published by Lewis at the age of twenty. ${ }^{7}$ This ushered in a career devoted to clinical research in the cardiovascular field. His pupils, in turn, included student contributors, and so ad infinitum!

Another University College Hospital student who caught the intellectual spark from great teachers was Joseph Samson Gamgee. This young man became imbued with revolutionary ideas concerning the treatment of fractures, at an early stage in his training. He wrote, in true Vesalian style, castigating what he saw daily around him, 'multifarious and inefficient contrivances rich in wood and leather, splints, straps and buckles, hooks and screws, bolts and hinges, which have been prolifically devised for the treatment of fractures.' Gamgee was not just a vitriolic student seeking attention. He dug in, worked hard, and in 1853 had the publisher-bookseller H. K. Lewis produce an 89-page volume for the market, entitled On the Advantages of the Starched Apparatus in the Treatment of Fractures and Diseases of the Joints-all before medical graduation. His essays on fractures and their more rational treatment were sufficiently well received by the faculty to bring Gamgee the Liston Clinical Medal-high praise in itself. It is little wonder that in his surgical training as a University College Hospital postgraduate, Gamgee sought out the service of another student contributor, John Erichsen, who had written his student thesis on coronary insufficiency and ventricular fibrillation. Gamgee worked as a pioneer in contour-fitting casts which respected the soft parts. His epitaph might well be his admonition to surgeons: 'There must be no squeezing like that of an old college friend's hand when seen after a long absence ... . the soothing surgical pressure is like that which you interchange with the hand of a lady.'

Henry Head (1861-1940) completed his pre-clinical work at Cambridge. Before 


\section{W. C. Gibson}

going to University College Hospital for clinics he spent two years at Prague and at Halle. To the former city he brought the game of soccer football which he later considered a mixed blessing. In the latter city he worked with Hering on the role of the vagus nerve in respiration ${ }^{8}$ and on the action potential of nerve. It is interesting that his M.D. thesis in London was 'On disturbance of sensation with special reference to the pain of visceral disease'. His classic work on sensation, and on aphasia following brain injuries in the Great War, gave him pre-eminence among neurologists. As poet, linguist and teacher, he was an ornament to any profession.

We must hurry on to the student contributors at other London hospitals. St. Bartholomew's provides us with many. Senior in the group was Thomas Young (1773-1829), otherwise known as 'Phenomenon Young', of Rosetta stone and 'modulus of elasticity' fame. ${ }^{9}$ This 'universal mind', of incredible inventiveness, is of particular interest to us in the field of vision. As a first-year student at St. Bartholomew's he was dissecting the eye of an ox, fresh from Smithfield Market nearby, when he discovered that the ciliary muscles, when stimulated mechanically, caused the shape of the lens to change. Within a year he was made a Fellow of the Royal Society for his research which this observation initiated. Young then transferred to Edinburgh to study with the chemist Joseph Black who, as a student, had discovered carbon dioxide. The multiplicity of interests which occupied Young is hard to believe today, for these encompassed agricultural genetics, copper-plate engraving, lens grinding, meteorology, foreign languages, surveying, botany and even the translating of Shakespeare into Greek. At Göttingen, where he took his doctorate in medicine, he added music, drawing, a phonetic universal alphabet of forty-seven characters, the separation of white light into colours and their recombination to produce the original light, the measurement of atoms and of red blood corpuscles, street-lighting by gas, standard weights and measures, and even shipbuilding. Few student discoveries are likely to be as dramatic, useful and quickly acclaimed as were those of Thomas Young.

James Paget entered St. Bartholomew's Hospital Medical College at the age of twenty, already an accomplished taxonomist, artist and linguist. With his brother Charles he had just published $A$ Sketch of the Natural History of Yarmouth and its Neighbourhood. In the course of his anatomical dissection Paget discovered some calcified pork parasites in the muscles of the cadavers. ${ }^{10}$ These supposed 'boney spicules' had been taken for granted since time began; but as Paget records it: 'My share was the detection of the "worm" in its capsule; and I may justly ascribe it to the habit of looking-out, and observing, and wishing to find new things, which I had acquired in my previous studies of botany. All the men in the dissecting room, teachers included, "saw" the little specks in the muscles; but I believe that I alone "looked at" them and observed them; no one trained in natural history could have failed to do so.'

Looking at them was not easy, for the head of Natural History at the British Museum, after delaying tactics, confessed that they owned no microscope with which to scan his preparations. At length one was unearthed in the Botanical side of the house and the encysted little invaders were studied with great attention. Thirty-five years later another medical student at Toronto, William Osler, was to rediscover these worms and to infect rabbits with them, for further study.

Jonathan Hutchinson (1828-1913) began his long career in medicine by studying, 


\section{Scientific Contributions of Medical Students in London}

in infants, the peculiarly notched teeth which we associate with syphilis. ${ }^{11}$ His undergraduate work extended also to observations on the inflammatory changes which ensued in the eyes of infants and young adults in the hereditary form of the disease.

A 'Bart's man' whose influence continues to increase, though he died in 1933, is Walter Morley Fletcher, the organizing genius of the Medical Research Council of Great Britain for the first twenty years of its existence. ${ }^{12}$ Fletcher graduated from St. Bartholomew's in 1900 and died at age sixty, in 1933. These were the critical years for the struggling Medical Research Council, not only financially, but in the tougher realm of trying to plant the idea of careerships in research as against a dabbling type of hobby research. His advanced ideas affected the Rockefeller trustees in America and the Tata trustees in India. Fletcher, two years before taking his medical qualification, did meticulous work in two important areas, one the anatomy of the sympathetic nervous system, and the other, the rate of production of carbon dioxide and lactic acid in muscle contraction. According to his friend, T. R. Elliott, ${ }^{13}$ also a youthful contributor on the autonomic adrenal system, Fletcher had a sense of mission about science serving society. Elliott wrote: 'He looked out over England and saw how little our people were receiving in bodily welfare from all the newly woven Science.' Fletcher's creed was that it was possible, and necessary, to narrow this gap. We think of Fletcher even away out at the rim of the Pacific whenever we take down to read one of his beautiful books, now housed in the Woodward Library.

One of the problems in subdividing London student contributors according to their hospital ties, is exemplified by John Hunter's life (1728-1793). ${ }^{14}$ He was educated at his brother William's Anatomy School in Great Windmill Street, at Cheselden's lectures at Chelsea Hospital, at St. Bartholomew's with Percival Pott, and, of course, at St. George's Hospital. Arriving in London, unlettered, at the age of twenty, John Hunter spent twelve years in dissecting, studying, and preparing himself as a surgeon. The copious notes which he made in these years were assembled in 1762, when, at age thirty-four, he was an Army Surgeon on the French island of Belle Isle. These notes were not published until the last year of his life-in his great volume entitled A Treatise on the Blood, Inflammation and Gun-shot Wounds (1794). There Hunter tells of his student days in London and of beginning experiments at St. George's Hospital. Concerning suppuration he wrote of cases observed when he was aged twenty-one. On the subject of oxygenated blood being distinctly red in colour, he notes that in 1755 (at age twenty-seven) he carried out experiments at St. George's. He notes the darkness of the blood in a case of emphysema there. His prose is difficult to follow, at times, but his ideas were those of a highly original mind.

Hunter's famous pupil at St. George's, Edward Jenner, ${ }^{15}$ was an experienced naturalist by the time he went up to London. He was so accomplished in this field that Captain Cook invited him to join his second expedition in 1772. Jenner showed then, as he did later, that he was not easily diverted from medical science. It is, in my view, entirely possible that Jenner as a medical apprentice conceived of vaccination with cowpox as a preventive of smallpox. His apprenticeship to Hunter was certainly as much one in experimental biology as in clinical medicine. His interest in heart disease was stimulated in his undergraduate years by a case of angina pectoris, treated by Heberden, and autopsied by John Hunter. At age forty Jenner wrote his famous 


\section{W. C. Gibson}

paper Remarks on a Disease of the Heart Following Acute Rheumatism, illustrated by Dissections.

Henry Gray (1827-1861) entered St. George's Hospital Medical School at age eighteen and became truly a 'do-it-yourself' dissector. ${ }^{16}$ As an undergraduate he wrote in a fine clear hand, a volume of 341 pages entitled: The Origin, Connection and Distribution of the Nerves of the Human Eye and its Appendages. At age twenty-one he won the Triennial Prize of fifty guineas given by the Royal College of Surgeons for this amazing 'essay', which was really a study in the phylogeny and comparative anatomy of all the neural elements entering the orbit, together with the organ of vision itself. There must have been few species of animal which escaped Gray's dissecting instruments. It should be stated at once that Gray was no dry-as-dust morphologist. He looked at the structure, both gross and microscopic, as subserving such functions as eyelid closure, pupillary dilation, and eyeball rotation. Within two years of qualifying Gray produced his next study, on the retina, optic nerve, membraneous labyrinth of the ear and the auditory nerve. The Royal Society made him a Fellow at age twenty-five, and he received the Astley Cooper Prize of 300 pounds for his paper: On the Structure and Use of the Spleen. Gray's Anatomy, Descriptive and Surgical, appeared when Gray was thirty-two. By age thirty-four he was dead of smallpox, thus robbing the world of his book on tumours. Few undergraduates have set their course in life as early and as completely as Gray did.

Perhaps I may add the name of Patrick Bosley, who did his pre-medical studies on capillary microscopy under my supervision in the Kinsmen Laboratory of Neurological Research at the University of British Columbia. He continued his researches on the microstructure of blood vessels while studying for his medical degree at St. George's. ${ }^{17}$

Guy's Hospital can claim a remarkably versatile student contributor in Richard Bright (1789-1858). ${ }^{18}$ After beginning medicine at Edinburgh, and pursuing natural history in Iceland with Sir George MacKenzie, Bright signed on at Guy's and studied with Sir Astley Cooper among others. There he began his studies on diseased kidneys and made his first drawing of a granular kidney. He spoke to the Physical Society 'On the Use and Abuse of Blood-Letting'. He produced a dissertation, 'On Gangrene', which he read before the Royal Medical Society in Edinburgh, of which he was made President. Bright's literary and artistic ability were noteworthy, although he might never have been in competition with that medical student of Guy's Hospital, C. S. Forester. The most important aspect of Bright's later career, to us at least, was his employment of four of his medical students in his research programme into what we now call 'Bright's Disease' of the kidneys. In his Gulstonian Lectures, Bright noted that from May to October 1842, his 'clinical investigation unit' at Guy's had prospered. He said: 'I have had great assistance from the intelligent and zealous co-operation of three of my young friends and pupils, Mr. Barlow, Mr. Tweedie, and Mr. Rees. These gentlemen have found from experiments made upon the urine of 296 patients, taken promiscuously in Guy's Hospital, that 44 , that is 15 per cent, were coagulated by heat; that 37 , or $121 / 2$ per cent, gave precipitates with nitric acid; and 26 , or $84 / 5$ per cent, gave precipitates with both.'

The microscopic examination of kidney tissue fell to another student, Robinson, and we are not surprised to find him, in later years, writing a book on kidney 


\section{Scientific Contributions of Medical Students in London}

pathology. Rees, for his part, produced a book on blood chemistry, dedicating it to Bright and acknowledging 'the kind encouragement received from you when, as a mere boy, I first entered upon the study of pathological chemistry'.

One is reminded of the employment of medical students by another clinical researcher at Guy's, the versatile Sir Arthur Hurst. ${ }^{10}$ It was in his Gulstonian Lectures, also, that reference was made to the assistance rendered by his students, Frank Cook, E. G. Slesinger, and Geoffrey Marshall-all of whom later joined Guy's staff. Kenelm Digby, the fourth student, became Clinical Professor of Surgery at Hong Kong. Long may the tradition continue!

A Nobel Prize winner, Frederick Gowland Hopkins, will be the last student discoverer from Guy's to be discussed in this brief review. ${ }^{20}$ Deserting an insurance office job because of boredom, he passed rapidly through a series of commercial chemical laboratories. With the examinations of the Institute of Chemistry as his goal, he attended University College courses, and through Sir Thomas Stevenson, joined a medico-legal laboratory at Guy's Hospital. Despite his long hours of employment he enrolled in the medical school there, and actually, as he says, 'kept some sort of research going'. His early work on the bombardier beetle was followed by a report on the pigment in the wings of butterflies-a uric acid derivative. The method of estimating this was greatly improved by this practical man. From this unlikely starting-point Hopkins began his long and valuable series of papers on protein intake, leading finally to his Nobel Prize contributions on the vitamins-or as they were known in his time-'unidentified accessory food factors'. At age thirty-three he qualified in medicine, and four years later joined Sir Michael Foster, the classics man turned chemist, at Cambridge. Before leaving London, however, he helped to found the Clinical Research Association which, among other things, operated a clinicopathological service for practitioners. Hopkins was a born inquirer who found his home in medicine, with enough unsolved problems ahead to last him a lifetime.

In moving from Guy's to St. Thomas's Hospital we should be mindful of the days, before 1825 , when they were united, and happily for us, the uncle of Sir William Osler brings this before us. ${ }^{2}$ Edward Osler (1798-1863) was the eldest brother of Featherstone Osler, William's father. After being apprenticed in Cornwall he came up to the United Hospitals in May, 1816. In the Osler Library at McGill there exist some manuscript notes which Edward took at Astley Cooper's lectures in 1816. At the age of nineteen Edward Osler read before the Abernethian Society in London: 'A dissertation on Nervous Influence. Life. The Will'. It is listed in the Bibliotheca Osleriana as 'part of a thesis'. The following year he qualified for the M.R.C.S. His letters to James Cornish, a physician in Falmouth, on life in London, are rather stark. He missed nothing! His first impression of London was written on 14 June 1816. He said: 'After a passage agreeable enough, we arrived at this infernal place on Tuesday fortnight. I took an antipathy to it the first moment I saw it. I have yet met with nothing that can induce me to change my opinion.' On leaving, scarce two years later, he wrote to his father in Falmouth: 'I shall feel some regret at leaving London . . . wherever I may finally pitch my tent I can never hope to experience more kindness than I have received from ... my friends in town. To Literary Society I must in a great degree bid goodbye and perhaps few have enjoyed that more than myself.' 


\section{W. C. Gibson}

A contemporary of Edward Osler's is to be found in the medical student, Benjamin Golding, who established a facility for the sick poor in 1815 , which eventually became Charing Cross Hospital. ${ }^{21}$ At the age of eighteen he entered upon his medical training at Edinburgh, moving to London, two years later, to follow the clinical teachers at St. Thomas's Hospital. Within a year of his arrival in London he took a house in Leicester Place which was to be the base for his care of all sick poor who sought his service gratuitously. With amazing maturity he wrote then: 'I consider that a young medical man ... cannot be employed more beneficially, either to himself or others, than in adding to his practical knowledge, and in extending, by every means in his power, his opportunities of seeing diseases in their multifarious forms and complications; and that, to attain this object and, at the same time, to render himself useful to others, he cannot do better than to devote some hours daily, for the first few years of his professional life, to the seeing and prescribing gratuitously on those sick persons who require his aid but are too poor to remunerate him.'

From 8 a.m. to 1 p.m. he practised medicine in this way, no formal qualification then being required. For two years he combined this strenuous work with attendance at St. Thomas's Hospital lectures and students' ward responsibilities. With his M.R.C.S. taken in 1817, he returned to Scotland-this time to St. Andrews for his doctorate in medicine. When he was twenty-six he completed his encyclopaedic report entitled, 'The Historical Account of the Origin and Progress of St. Thomas's Hospital, Southwark' (1816). This analysis of that hospital and of Guy's was to be the guiding principle in establishing his Charing Cross Hospital. In the three years, 1815 to 1818 , we should recognize that this young man saw 20,000 patients in his house, after which time, he and two senior men opened an actual hospital at 16 Suffolk Street, behind the Haymarket Theatre and beside the United Universities Club which dates from almost that time.

The colourful surgical genius Astley Cooper (1768-1841) began the medical career as an apprentice to a Guy's Hospital man, William Cooper, his uncle. ${ }^{22}$ Then he joined Henry Cline, the moving spirit in surgery at St. Thomas's Hospital-a pupil of John Hunter. As an undergraduate, Cooper, with his friends Holland and Coleman, began a series of experiments on collateral circulation. These they performed at Mr. Cline's house. For seven months Cooper went off to study at Edinburgh where, it can be said, he quickly became the most popular student in the medical school. On returning to London, Cooper plunged into further animal research on respiration, again with Coleman. Mr. Cline invited Cooper to do most of his lecturing in surgery, surely a thrill for any undergraduate.

Our final St. Thomas's man, Charles Scott Sherrington, needs no introduction to Oslerians. ${ }^{23}$ At Oxford he was one of Osler's most intimate friends. He had first encountered Osler at meetings of the British Association for the Advancement of Science at Bristol and Oxford, in 1894. Almost twenty years later Osler was to be chairman of the Board of Electors to the Waynflete Chair of Physiology when, in 1913, Sherrington was invited to come to Oxford.

Sherrington's life is an epic-a struggle of grey matter against adversity. His whole biography will probably never be written-but I can tell you from personal knowledge that his outgoing, generous and, above all, creative life, was cast against 


\section{Scientific Contributions of Medical Students in London}

a background of always precarious support and of too little public appreciation of what he was attempting to do. He saw to it that everyone else in the neurological or physiological field was nominated for the Nobel Prize. Belatedly, I feel, he shared it in 1932. When John Fulton wrote that Sherrington had done for the nervous system what Harvey had done for the circulatory system, he was stating a fact not always recognized. The year 1881 found Sherrington a medical student at Caius College, Cambridge, ready to go up to St. Thomas's for his clinical work. His tutor, the famous John Newport Langley, physiologist and editor, brought back to Cambridge half of the brain of Goltz's famous partly-decorticated dog which caused so much acrimonious discussion at the Seventh International Medical Congress just concluded in London. Sherrington's earliest student research was conducted with Langley on this brain, and their findings were published in 1884. In 1885 Sherrington's further paper on this subject appeared in the Journal of Physiology. After demonstrating in anatomy with Sir George Humphry at Cambridge, Sherrington completed his clinical work at St. Thomas's. Here he continued demonstrating, this time in microscopic anatomy. The fact is not always grasped that Sherrington was first a histologist, then a pathologist-in fact a pupil of Rudolph Virchow. Only after all this did he become the greatest physiologist of his era, starting from a lectureship in physiology at St. Thomas's. His undergraduate interest in the nervous system never deserted Sherrington over the course of his long life of ninety-five years; his student years determined much of his eventual course.

There will be time to discuss only one undergraduate contributor from each of King's College, Charing Cross and the London Hospitals. At King's College Hospital Medical School we must turn our attention to the student anatomist, Frederick Oldfield Ward (1818-1877). ${ }^{24}$ His entry into the medical school at the age of fifteen seems to us today incredible. Within two years he had won a medal in chemistry and by age nineteen had taken the medal in botany. As if this were not enough, he published, at age twenty, his undergraduate contribution, Outlines of Human Osteology. Three editions had appeared by the time he died in 1877 , in a mental hospital. For comprehensiveness, Ward's survey of the existing literature on human bony structure was remarkable. He sought brevity 'not in expressing ideas in a small space but in conveying them in a short time'. He worked at his book for the five years of his undergraduate life. He was thorough; he says: "Whatever contradictory statements came under my notice in the course of this comparison were noted down, and made the subject of careful research in several extensive anatomical collections . . . which afforded me the opportunity of comparing nearly two hundred specimens of each bone.' What we still call 'Ward's Triangle' in the neck of the femur he illustrated by a simple diagram showing the head of the femur as an old gas lamp, supported by a triangle, the base of which was the upper segment of the standard or pole against which the lamp-lighter of those days would prop his little ladder. Another triangle was shown to exist in the calcaneum of the foot, both being referred to, in modern radiology, by Ward's name. As his classmate at King's, Sir John Simon, records, Ward, after a querulous life in public pursuits, was lodged in St. George's Retreat, where he died at age 59.

Thomas Henry Huxley (1825-1895) entered Charing Cross Medical College in 


\section{W. C. Gibson}

1842, at the age of seventeen. ${ }^{25}$ The world has never been the same since! He had already been reading geological books for five years, interspersed with logic and German, self-taught. From his diary we know that, at age fifteen, he was concerned with the injustice of compulsory support of a state church. By age sixteen he recorded: 'I have been pondering for some time over a classification of knowledge'. Being too young for admission to the University of London, Huxley wisely sought out the hospitable library of the Royal College of Surgeons. Were Huxley alive today, he would be right back there reading-for the same hospitable spirit prevails-something to which Sherrington introduced me thirty-two years ago. As an undergraduate of nineteen Huxley produced his first research paper entitled: 'On a hitherto undescribed structure in the human hair sheath'. We still refer to it as 'Huxley's layer'. A great teacher was certainly the stimulus here. Huxley has written of him: 'The only instruction from which I obtained the proper effect of education was that which I received from Mr. Wharton Jones, who was the lecturer on physiology . . . The extent and precision of his knowledge impressed me greatly, and the severe exactness of his method of lecturing was quite to my taste. I do not know that I have ever felt so much respect for a teacher before or since ... It was he who suggested the publication of my first scientific paper-a very little one-in the Medical Gazette of 1845, and most kindly corrected the literary faults which abounded in it.'

Wharton Jones's influence persisted after graduation for we find Huxley as assistant surgeon on the H.M.S. Rattlesnake, bound for Australia, writing: 'I must keep two points in view, 1st that $I$ am simply a student, 2 nd from the peculiar circumstances in which I am placed, care and caution in observation may help me to become a teacher ... As Darwin's 'bulldog', Huxley more than fulfilled his earlier aspirations as a teacher.

And finally we come to that unsung medical hero of two world wars, Martin Flack, a product of the London Hospital Medical College. ${ }^{26}$ Born in a good cardiovascular county, Kent, he studied at Oxford with Arthur Thomson the anatomist and Francis Gotch the physiologist. Alas, he was just too soon for Osler! However, Flack, on completing his pre-clinical work at Oxford, returned to his home in the village of Borden, Kent, to find that the Professor of Anatomy from the London Hospital had just taken a weekend cottage nearby. Through the 'underground' which only such villages can supply, Flack soon met Arthur Keith, who put him to work cutting thin sections of 130 hearts for microscopic examination. Before long Flack noticed a 'new' structure turning up in all the sections. It was so far removed from the already described auriculo-ventricular conducting fibres that its nature was at first a mystery. Today we call it the 'sino-auricular node'-the all-important pacemaker structure of the heart. Within a few months of beginning on this research, it was possible for Flack and Keith to write their pioneer paper by Christmas of 1906 and to see it published in the Journal of Anatomy and Physiology early in 1907. The mixture of histology and golf which had occupied teacher and student for several concentrated months of work had paid off handsomely. Further student research was carried on in the laboratory of Leonard Hill, on respiratory and circulatory tests of fitness, all of which were later applied in aviation medicine. Flack went on to graduate in 1908, to win a Radcliffe Travelling Fellowship which took him to Switzerland for work with 


\section{Scientific Contributions of Medical Students in London}

Asher and Kronecker. When the Medical Research Council set up its Applied Physiology Laboratory in London, in 1913, Flack joined Hill in developing the aviation medical work which held up well in the First World War. It was summarized by Flack in his Milroy Lectures before the Royal College of Physicians in 1921. Sad to say, Flack was dead ten years later of septicaemia. His discoveries and, above all, his teaching had a prolonged effect which carried over into the Second World War in 1939. Without Flack and his student research, I doubt if we would have been ready for the Battle of Britain.

Thus we come to the end of this too superficial examination of a fascinating aspect of medical history-one which I feel sure would have intrigued Sir William. The Oslerians here will, I trust, consider it but a small instalment of an old debt which I have long owed to many of them.

\section{REFERENCES}

1. Abbott, Maude E., 'The pathological collections of the late Sir William Osler at McGill University', Bull. Internat. Assn. Med. Museums, 1926, 10, 185-99.

2. Cushing, H. W., The Life of Sir William Osler, Oxford, Clarendon Press, 1926, p. 85.

3. LeAKE, C. D., 'Gold Rush doctor', Gesnerus, 1951, 8, 114-23.

4. LisTER, JosePH, 'Observations on the muscular tissue of the skin', Quart. J. microsc. Sci., 1853, 1, 8-17.

5. Dobson, Jessie, 'Frederick Augustus Dixey', J. Bone Jt. Surg., 1949, 31B, 596-99.

6. Paget, StePHen, Sir Victor Horsley. A Study of his Life and Work, London, Constable, 1919.

7. LeWIS, THOMAs, 'Observations on the functions of the spleen and other haemolymph glands', J. Anat. Physiol., 1904, 38, 144-57.

8. Head, HenRY, 'On the regulation of respiration', J. Physiol. (Lond.), 1889, 10, 1-70, 279-90.

9. Oldham, Frank, Thomas Young, F.R.S., Philosopher and Physician, London, Edward Arnold, 1933.

10. Paget, Sir James, Memoirs and Letters, London, Longmans Green, 1901, pp. 55, 57.

11. Hutchinson, HeRBert, Jonathan Hutchinson, Life and Letters, London, W. Heinemann, 1946.

12. FleTCHER, M. F., The Bright Countenance: a Personal Biography of Walter Morley Fletcher, London, Hodder \& Stoughton, 1957.

13. Dale, Sir Henry, An Autumn Gleaning. Occasional Lectures and Addresses, London, Pergamon, 1954, p. 216.

14. HUNTER, John, A Treatise on the Blood, Inflammations, and Gun-shot Wounds, London, George Nichol, 1794.

15. DREWITT, F. DAWTREY, Life of Edward Jenner, London, Longmans Green, 1933.

16. Gibson, William C., 'Henry Gray (1827-1861),' in: Young Endeavour, Springfield, Ill., C. C. Thomas, 1958, pp. 22-23.

17. Bosley, P. G. H. J., and Gibson, William C., 'Photomicrographic studies on the nailbed capillaries in patients who are mentally ill', Bibliotheca Anatomica, 1964, 4, 595-616.

18. Gibson, William C., 'Contributions by medical undergraduates', in: Creative Minds in Medicine, Springfield, Ill., C.C. Thomas, 1963, pp. 184-87.

19. HURST, SIR ARTHUR, A Twentieth-Century Physician, London, Edward Arnold, 1949.

20. SherRINGTon, C. S., Obituary notice of F. G. Hopkins, Lancet, 1947, i, 728-31.

21. Minney, R. J., The Two Pillars of Charing Cross, London, Cassell, 1967. 


\section{W. C. Gibson}

22. Brock, R. C., The Life and Work of Astley Cooper, Edinburgh, E. \& S. Livingstone, 1952.

23. PENFIELD, WIIDER, 'Sir Charles Sherrington', in: The Second Career, Boston/Toronto, Little, Brown \& Co., 1963, pp. 66-75.

24. Dobson, Jessie, 'Frederick Oldfield Ward', J. Bone Jt. Surg., 1949, 31B, 596-99.

25. HuXley, LeONARD, Life and Letters of Thomas Henry Huxley, 2nd ed., 3 vols., New York, Macmillan, 1903.

26. Flack, MARTIN, Milroy Lectures, Lancet, 1921, ii, 637, 693. Obituary note, Lancet 1931, ii, 430, 510; Brit. med. J., 1931, ii, 402. 